\title{
The Prognostic Significance of c-Met and p53 Immunohistochemical Expression in Gastric and Colorectal Carcinomas
}

\author{
Amany A. Abou-Bakr ${ }^{1}$, Alshaymaa A. Abdelaziz ${ }^{2}$, Ibrahim A. Malash ${ }^{2}$, Osman Mansour ${ }^{2}$, Ibrahim M. Abdelsalam $^{3}$, \\ Omnia M. Abo-Elazm ${ }^{4}$, Heba A. Ibrahim ${ }^{5}$, Mai S. Mohammed ${ }^{5}$, Rasha A. Khairy ${ }^{5}$ \\ ${ }^{1}$ Department of Pathology, National Cancer Institute, Cairo University, Cairo, Egypt; ${ }^{2}$ Department of Medical Oncology, National \\ Cancer Institute, Cairo University, Cairo, Egypt; ${ }^{3}$ Department of Tumor Biology, National Cancer Institute, Cairo University, \\ Cairo, Egypt; ${ }^{4}$ Department of Biostatistics and Cancer Epidemiology, National Cancer Institute, Cairo University, Cairo, Egypt; \\ ${ }^{5}$ Department of Pathology, Faculty of Medicine, Cairo University, Cairo, Egypt
}

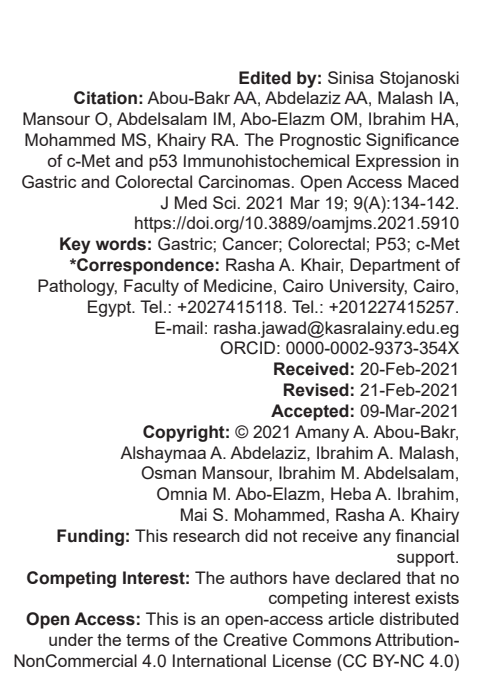

Abstract

BACKGROUND: Colorectal and gastric carcinomas are the most common and deadly gastrointestinal (GIT) malignancies.

AIM: This study aimed to evaluate the expression of c-Met and p53 in gastric and colorectal carcinomas (CRCs) as well as colorectal adenomas using immunohistochemistry.

MATERIALS AND METHODS: c-Met and p53 immunohistochemical expression was conducted on 66 cases of gastric adenocarcinomas and total of 60 colonic cases (36 CRCs and 24 colorectal adenomas).

RESULTS: In this study, c-Met was positively expressed in $54.5 \%$ of gastric carcinomas and $50 \%$ of CRCs. In addition, p53 was positively expressed in $56.1 \%$ of gastric carcinomas and $72.2 \%$ of CRCs. Moreover, higher expression of both $c-$ Met $(p=0.001)$ and $p 53$ expression $(p<0.001)$ was reported in CRCs compared to colorectal adenomas. In the same context, c-Met and p53 expressions were positively correlated with intestinal type gastric adenocarcinoma ( $p<0.001$ and $p=0.03$, respectively). Moreover, c-Met was correlated with non-mucinous adenocarcinomas $(p=0.008)$ and lower grades $(p<0.001)$ of gastric carcinomas. As regard survival analysis in gastric carcinomas, median overall survival (OS) was better in p53 positive patients $(p=0.05)$, patients with negative lymph node metastasis $(p=0.03)$, and patients with better response to neoadjuvant chemotherapy $(p=0.04)$. In contrast, c-Met did not exhibit significant correlation with OS $(p>0.05)$. Both c-Met and p53 did not reveal significant correlation with tumor stage and site in both CRCs and gastric carcinomas $(p>0.05)$

CONCLUSION: We concluded that c-Met and p53 are expressed in the most common GIT malignancies addressing them as potential biomarkers. In addition, c- Met and p53 may have a potential role in colorectal cancer development as they showed higher positivity in CRCs compared to adenomas.

\section{Introduction}

Colorectal and gastric cancers are the most common gastrointestinal (GIT) malignancies [1]. Colorectal cancer (CRC) occupies the third rank among worldwide cancers and despite the major advances in chemotherapeutic protocols, it is still the second leading cause of cancer-related mortality [2].

Stomach cancer is the fifth most common malignancy in the world [3]. In Egypt, the incidence rate of gastric cancer in males was $2.5 \%$ and for females was $1.6 \%$ in Upper Egypt [4].

Molecular testing targeting specific oncogene has been a promising approach in treatment of cancer. The tyrosine kinase receptor c-Met, which is located on the q-arm of chromosome 7, was found to be overexpressed in some carcinomas [2], [5].
Activation-overexpression of the tyrosine kinase receptor c-Met enhances the tumor invasiveness through the control of cellular proliferation, growth, epithelial-mesenchymal transition and cell migration, and its associated ligand hepatocyte growth factor (HGF). c-Met overexpression in cancer colon has been associated with increased invasive potential, lymph node, and liver metastasis [6]. As regard to gastric carcinoma, Huang et al. stated that c-Met expression was correlated with adverse prognostic factors [7].

P53 is a tumor suppressor gene, mapped on chromosome $17 q 13.1$ is uniformly considered as the genome guardian and a major player in regulation of cell cycle, DNA repair, and apoptosis. Tumorigenesis can be promoted through uncontrolled cell growth due to failure of induction of cell death which results from p53 mutation. In normal tissues, p53 gene is not detected by immunohistochemical analysis but mutated p53 has longer half-life; thus, it accumulates 
in the cell nucleus and its expression can be detected by immunohistochemistry [8], [9]. P53 gene mutations have been detected in multiple malignancies [10].

In the current study, we aimed to illustrate feasibility and importance of detection of c-Met and pP53 mutations as potential biomarkers in gastric and colorectal carcinomas (CRCs) as well as the premalignant colorectal adenomas using immunohistochemistry.

\section{Materials and Methods}

This study was conducted after approval by ethics committee at National cancer institute $(\mathrm{NCl})$, Cairo University as well as Pathology department, Faculty of medicine, Cairo University.

The paraffin blocks of total 66 patients who were diagnosed as operable non-metastatic gastric carcinoma in the $\mathrm{NCl}$, Cairo University in the period from January 2014 to January 2017 were retrieved and the patients' medical records were reviewed. All patients received neo-adjuvant or adjuvant therapy. Treatment response after neoadjuvant therapy was assessed according to the RCIST criteria [11]; as follow: Complete response, partial response, progressive disease, or stable disease. Overall survival (OS) and disease free survival (DFS) were calculated.

In addition a total of 60 paraffin embedded colonic tissue sections (24 archived paraffin blocks of colorectal adenomas obtained through colonoscopic biopsies and 36 archived paraffin blocks of CRCs obtained through colectomy specimens) were also retrieved from the pathology department, Faculty of Medicine, Cairo University, during the period from January 2018 to December 2018. The medical records were revised for obtaining of the clinicopathologic data available. The data for survival analysis for cancer colon patients were not feasible.

\section{Histopathologic examination}

Hematoxylin and Eosin slides of all gastric and CRCs were re-examined. The histologic variants were classified according to the WHO criteria [12] and staging was done according to tumor, node, and metastasis classification for cancers of the colon and rectum [13].

Grade of dysplasia into low and high grade colorectal adenomas based on their architectural features and cytological features was also documented [14].

\section{Immunohistochemical staining}

From each of gastric and $\mathrm{CRC}$ cases as well as colorectal adenomas, two unstained sections were prepared on positively charged slides for the immunohistochemical assessment of the studied markers.

P53 (DO-1), Rabbit monoclonal antibodies (Thermo Fisher) and c-Met (SP44), and Rabbit monoclonal antibodies (Spring Bioscience) were applied. Positive control (breast carcinoma) was included on each run. Paraffin sections were made at 4 microns thickness and mounted on positive charged slides. Immunostaining was done for all cases using Bench Mark XT (Ventana) auto-strainer and the following steps occurred automatically: De-paraffinization using the EZ-prep solution, cell conditioning (standard cell conditioning CC1) for $64 \mathrm{~min}$, antigen retrieval using reaction buffer $(\mathrm{PH}$ 7.4-7.8), application of $100 \mu$ of each of the readyto-use monoclonal antibodies used in the study under specific incubation temperature and time for each. Application of diaminobenzidine (DAB) as a chromogen (NexES UltraView DAB Detection Kit) and counterstaining with Hematoxylin II for 8 min was subsequently done. Slides were cleared in xylene, and then cover slips were applied. Assessment of immunostaining was performed using Olympus light microscope (CX31).

\section{Immunohistochemical evaluation}

Sections from gastric carcinomas and CRC cases as well as colorectal adenomas were scored as positive for p53 when $>10 \%$ of tumor cells displayed nuclear immunostaining.

Immunoreactivity for c-Met protein was located in both membrane and cytoplasm, and the intensity and frequency of stained cells were evaluated. The staining intensity was scored as follows:

weak $=1+;$ moderate $=2+;$ intense $=3+$.

For frequency: $1=5-25 \% ; 2=26-50 \%$; $3=51-75 \%$ and $4=>75 \%$.

The final score was the product of the two former values. Tumors with $0-1$ were designated as negative; all others were considered positive.

\section{Statistical methods}

SPSS win statistical package version 21 was used for data analysis (SPSS Inc., Chicago, IL). Numerical data were expressed as mean and standard deviation or median and range as appropriate. Qualitative data were expressed as frequency and percentage. The relation between qualitative variables was examined by Chi-square test (Fisher's exact test). For quantitative data, student t-test or Mann-Whitney test (non-parametric t-test) were used to compare between two groups as appropriate. $p \leq 0.05$ was considered significant. 
All survival estimates were calculated by Kaplan-Meier method. Other predictor and prognostic variables were related to survival using log rank test.

\section{Results}

A total of 60 paraffin embedded colonic tissue sections from colorectal adenomas $(n=24)$ and, CRCs $(n=36)$ were enrolled in this study. The patient's age with CRC ranged from 28 to 83 years with (mean \pm SD) $59.9 \pm 12.6$. For colorectal adenomas, patients mean age $\pm S D$ was $56.0 \pm 14.3$.

The clinico-pathological characteristics of colorectal adenoma and CRC patients are summarized in Tables 1 and 2, respectively.

Table 1: Clinicopathologic data of the studied colorectal adenomas cases

\begin{tabular}{lll}
\hline Clinicopathological data & Colorectal Adenomas & \\
\cline { 2 - 3 } & Count & $\%$ \\
\hline Sex & 19 & 79.2 \\
$\quad$ Male & 5 & 20.8 \\
$\quad$ Female & 10 & 41.7 \\
$\begin{array}{l}\text { Grade of dysplasia } \\
\text { Low }\end{array}$ & 14 & 58.3 \\
$\quad$ High & 6 & 25.0 \\
Histological variant & 18 & 75.0 \\
$\quad$ Tubular adenoma & 12 & 50.0 \\
$\quad$ Tubulovillous & 10 & 41.6 \\
Site & 2 & 8.3 \\
$\quad$ Right colon & & \\
$\quad$ Left colon & Rectosigmoid &
\end{tabular}

c-Met and p53 were expressed in colorectal adenomas and carcinomas as positive brown, cytoplasmic and nuclear immunostain respectively in tumor epithelial cells. c-Met positive expression in was detected in $50 \%$ of CRCs, $78.6 \%$ of high grade adenomas, while it was totally negative in low grade adenomas with statistically significant correlation $(p=0.001)$. In the same context, p53 showed negative expression in all adenomas, while $72.2 \%$ of invasive

Table 2: Clinicopathological data of the studied colorectal carcinoma cases

\begin{tabular}{lll}
\hline Clinicopathological data & Colorectal cancers & \\
\cline { 2 - 3 } & Count & $\%$ \\
\hline Sex & 17 & 47.2 \\
$\quad$ Male & 19 & 52.8 \\
$\quad$ Female & & \\
Histological variant & 31 & 86.2 \\
$\quad$ Adenocarcinoma & 5 & 13.8 \\
$\quad$ Mucinous adenocarcinoma & & \\
Grade & 32 & 88.9 \\
II & 4 & 11.1 \\
III & 6 & \\
Tumor depth of invasion (T) & 21 & 16.7 \\
2 & 4 & 58.3 \\
3 & 5 & 11.1 \\
4a & & 13.9 \\
4b & 17 & 47.2 \\
Nodal status & 7 & 19.4 \\
O & 4 & 11.1 \\
1a & 5 & 13.9 \\
1b & 3 & 8.3 \\
2a & & \\
2b & 12 & 34.3 \\
Site & 14 & 40.0 \\
RT & 9 & 25.7 \\
LT & & \\
Sigmoid & &
\end{tabular}

CRC showed positive p53 expression with statistical significance $(p<0.001)$. The correlation between c-Met and p53 immunohistochemical expression in colorectal adenomas and carcinomas is summarized in Table 3.

Table 3: The correlation of c-Met and P53 expression among adenomas low grade dysplasia, adenomas high grade dysplasia, and colorectal carcinomas

\begin{tabular}{|c|c|c|c|c|c|c|c|}
\hline \multirow[t]{2}{*}{$\begin{array}{l}\text { Tumor } \\
\text { marker }\end{array}$} & \multicolumn{2}{|c|}{$\begin{array}{l}\text { Adenoma (low } \\
\text { grade dysplasia }\end{array}$} & \multicolumn{2}{|c|}{$\begin{array}{l}\text { Adenoma (high } \\
\text { grade dysplasia) }\end{array}$} & \multicolumn{3}{|c|}{ Colorectal cancers } \\
\hline & Count & $\%$ & Count & $\%$ & Count & $\%$ & $p$ value \\
\hline \multicolumn{8}{|l|}{ c-Met } \\
\hline Negative & 10 & $100.0 \%$ & 3 & $21.4 \%$ & 18 & $50.0 \%$ & 0.001 \\
\hline Positive & 0 & $0 \%$ & 11 & $78.6 \%$ & 18 & $50.0 \%$ & \\
\hline \multicolumn{8}{|l|}{ P 53} \\
\hline Negative & 14 & $100.0 \%$ & 10 & $100 \%$ & 10 & $27.8 \%$ & $<0.001$ \\
\hline Positive & 0 & $0 \%$ & 0 & $0 \%$ & 26 & $72.2 \%$ & \\
\hline
\end{tabular}

In addition, c-Metand p53immunohistochemical testing in 36 primary CRC were analyzed and correlated with clinico-pathologic parameters as presented in Table 4, without significant correlation detected with histologic type, grade, stage, and site of CRCs $(p>0.05)$.

Regarding gastric carcinomas, a total of 66 paraffin embedded tissue sections were enrolled in this study. The patients' age with gastric carcinomas ranged from 25 to 74 years with (mean \pm SD) $52 \pm 10$.

The clinico-pathologic characteristics of gastric carcinoma patients are summarized in Table 5.

In addition, c- Met and p53 immunohistochemical testing were evaluated in the studied gastric carcinoma cases and correlated with clinic-pathologic parameters as presented in (Table 6). c-Met immunohistochemical expression in tumor cells was detected in $54.5 \%$ of gastric carcinomas and was positively correlated with nonmucinous adenocarcinomas $(p=0.008)$, intestinal type $(p<0.001)$, and lower histologic grades of gastric carcinoma $(p<0.001)$, while $p 53$ was detected in $56.1 \%$ of cases and was positively correlated with intestinal type gastric adenocarcinoma only ( $p=0.03)$.

No significant correlation was detected between c-Met and p53 expression in gastric carcinomas and other clinico-pathologic variables as tumor stage and, site $(p>0.05)$.

Immunohistochemical expression for c-Met in colorectal adenomas, CRCs and gastric carcinomas are shown in Figure 1a-d.

Immunohistochemical expression for p53 in colorectal adenomas, CRCs and gastric carcinomas are shown in Figure 2a-d.

The median OS of the whole group of gastric carcinomas was 27.4 months, 1-year OS was $80.7 \%$ and 2-years OS was $50.3 \%$ while 3 years OS was $45.7 \%$. The median DFS of the whole group of gastric carcinomas was 17.4 months, the 1 -year DFS was $55.1 \%, 2$ years DFS was $40.1 \%$, and 3 years DFS was $37.6 \%$. 


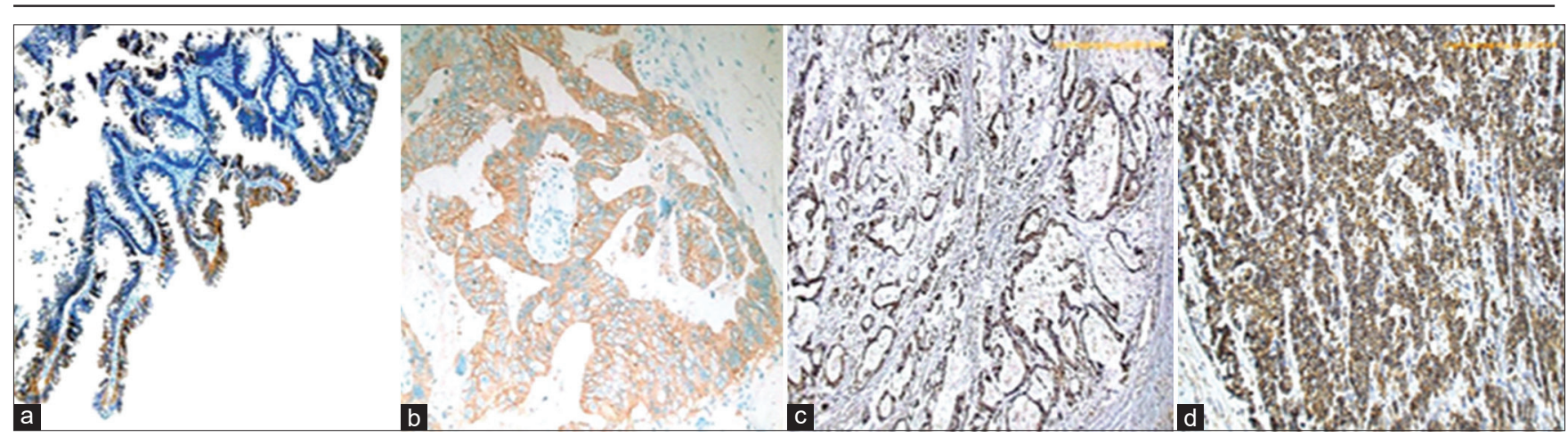

Figure 1: (a) Colonic tubulovillous adenoma with high grade dysplasia showed positive c-Met expression (IHC $\times 100)$, (b) colonic adenocarcinoma Grade II showed positive c-Met expression (IHC ×200), (c) gastric adenocarcinoma Grade II showed positive c-Met expression (IHC $\times 100)$, (d) gastric adenocarcinoma (diffuse type) showed positive c-Met expression (IHC $\times 200)$
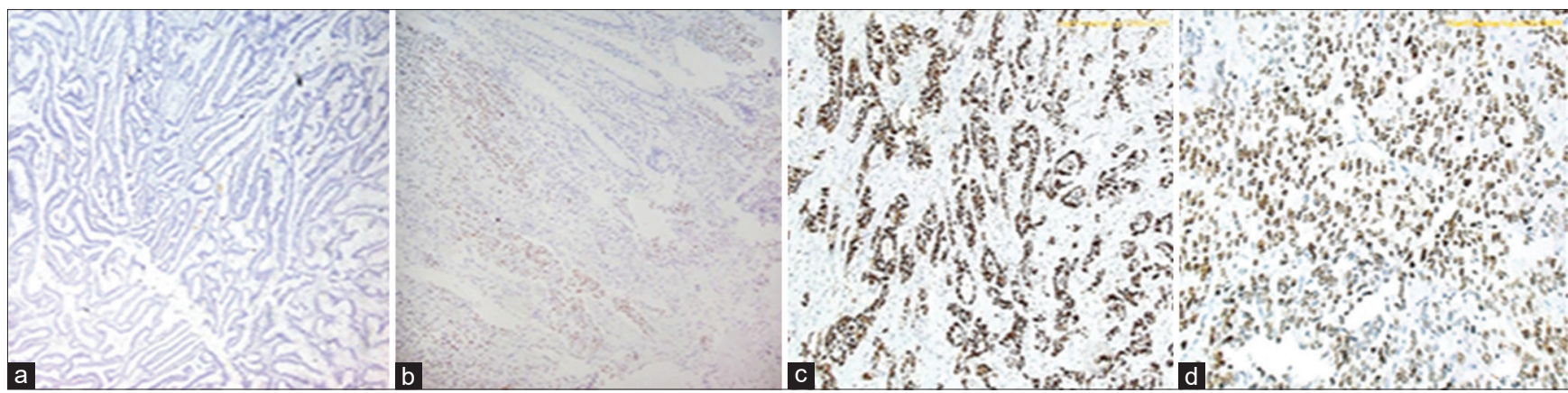

Figure 2: (a) Colonic tubular adenoma with low grade dysplasia showed negative $p 53$ expression $(\mathrm{IHC} \times 200)$, (b) colonic adenocarcinoma Grade II showed positive p53 expression (IHC $\times 100$ ), (c) gastric adenocarcinoma Grade II showed positive p53 expression (IHC $\times 100$ ), (d) gastric adenocarcinoma (signet ring) showed positive p53 expression $(I H C \times 200)$

Table 4: The correlation between c-Met and p53 expression with different clinicopathological parameters in colorectal carcinomas

\begin{tabular}{|c|c|c|c|c|c|c|c|c|c|c|}
\hline \multirow[t]{2}{*}{ Clinicopathological data } & \multicolumn{4}{|c|}{ c-Met } & \multicolumn{6}{|l|}{$\mathrm{P} 53$} \\
\hline & \multicolumn{2}{|c|}{ Negative } & \multicolumn{2}{|c|}{ Positive } & $p$ value & \multicolumn{2}{|l|}{ Negative } & \multicolumn{2}{|c|}{ Positive } & \multirow[t]{2}{*}{$p$ value } \\
\hline \multicolumn{10}{|l|}{ Histologic Type } & \\
\hline Adenocarcinoma & 15 & $83.3 \%$ & 16 & $88.9 \%$ & 1.00 & 9 & $90.0 \%$ & 23 & $88.5 \%$ & 1.00 \\
\hline Mucinous & 3 & $16.7 \%$ & 2 & $11.1 \%$ & & 1 & $10.0 \%$ & 3 & $11.5 \%$ & \\
\hline \multicolumn{11}{|l|}{ Grade } \\
\hline II & 16 & $88.9 \%$ & 16 & $88.9 \%$ & 1.00 & 9 & $90.0 \%$ & 23 & $88.5 \%$ & 1.00 \\
\hline III & 2 & $11.1 \%$ & 2 & $11.1 \%$ & & 1 & $10.0 \%$ & 3 & $11.5 \%$ & \\
\hline \multicolumn{11}{|l|}{ Stage } \\
\hline I, II & 9 & $50 \%$ & 7 & $38.9 \%$ & 0.338 & 5 & $50 \%$ & 11 & $42.3 \%$ & 0.722 \\
\hline III, IV & 9 & $50 \%$ & 11 & $61.1 \%$ & & 5 & $50 \%$ & 15 & $57.7 \%$ & \\
\hline \multicolumn{11}{|l|}{ Site } \\
\hline Right colon & 6 & $35.3 \%$ & 6 & $33.3 \%$ & 1.00 & 3 & $30.0 \%$ & 9 & $34.6 \%$ & 0.349 \\
\hline Left colon & 7 & $41.2 \%$ & 7 & $38.9 \%$ & & 0 & $0 \%$ & 4 & $15.4 \%$ & \\
\hline Recto-sigmoid & 4 & $23.5 \%$ & 5 & $27.8 \%$ & & 7 & $70 \%$ & 13 & $50.0 \%$ & \\
\hline
\end{tabular}

OS and DFS were correlated with different clinico-pathologic parameters as well as treatment strategies as shown in Table 7.

The median OS was superior in the $\mathrm{P} 53$ mutated/positive patients (40.8 months), while inferior in the negative ones (18.9 months) $(p=0.05)$. Furthermore, the median OS was superior in the node negative group (median OS was not reached as less than half of patients died), while in the node positive group (18.2 months) $(p=0.03)$. Moreover, the patients who showed good response to chemotherapy had significantly better OS, where the median OS in the responders was 19.8 months, while in the nonresponders was 7.5 months $(p=0.04)$.

There was a statistically significant relationship between DFS and the pattern of therapy given in gastric carcinoma patients, where the median DFS was superior in the adjuvant therapy group (22.3 months), followed by the perioperative therapy group (11.4 months) then, the neoadjuvant given therapy group ( 4.9 months $)(p=0.006)$.

Figure 3a-d demonstrated the OS curves and DFS curves in studied gastric carcinoma patients in relation to p53 and, c-Met immunohistochemical expression, respectively.

\section{Discussion}

According to GLOBOCAN 2018 data, worldwide colorectal and gastric cancers are the 
second and third leading cause of cancer deaths, respectively [3], [15].

To date, surgery combined with chemoradiotherapy is the classic strategy for treatment of GIT cancers. However, the long-term survival rate is still low [16]. Thus, investigating the role of specific oncogenes and tumor suppressor genes that may reflect the biological behavior of tumors is in increasing demand.

This study tried to illustrate detection of both tumor suppressor gene c-Met and p53 protooncogene in gastric and colonic carcinomas using immunohistochemistry as easy and readily available methods. In addition, as the majority of CRCs arise through transformation of adenomatous polypi [17], [18]; analysis of p53 and c-Met expression in colorectal adenomas has been carried out.

In the present study, the proto-oncogene c-Met, a member of the RTK family, and a known HGF receptor that is encoded by the MET gene, was expressed in

Table 5: Clinicopathological data of the studied gastric carcinomas cases

\begin{tabular}{lll}
\hline Clinicopathological data & Gastric carcinomas & \\
\cline { 2 - 3 } & Count & $\%$ \\
\hline Sex & & \\
Male & 52 & 78.8 \\
Female & 14 & 21.2 \\
Histological variant & & 69.7 \\
Adenocarcinoma & 46 & 9.1 \\
Mucinous adenocarcinoma & 6 & 21.2 \\
Signet ring cell carcinoma & 14 & 59.1 \\
Intestinal versus diffuse & & 40.9 \\
Intestinal & 39 & \\
Diffuse & 27 & 1.5 \\
Grade & & 60.6 \\
I & 1 & 37.9 \\
II & 40 & \\
III & 25 & 3.0 \\
Tumor depth of invasion (T) & & 21.2 \\
1 & 2 & 71.2 \\
2 & 14 & 4.5 \\
3 & 47 & \\
4 & 3 & 45.5 \\
Nodal status & & 27.3 \\
0 & 30 & 15.2 \\
1 & 18 & 12.1 \\
2 & 10 & \\
3 & & 31.8 \\
Site & & 68.2 \\
Proximal & 21 & 15.2 \\
Distal & 45 & 59.1 \\
Stage & & 25.8 \\
I & 10 & \\
II & 39 & \\
III & 17 & \\
& & \\
\hline
\end{tabular}

(54.5\%) of gastric carcinomas and in $72.2 \%$ of CRCs. c-Met expression in both studied CRCs and gastric carcinoma cases was not correlated with tumor site and stage $(p>0.05)$.

The previous studies also revealed absence of c-Met correlation with various parameters as, tumor site and stage in CRC [19], [20] and others in gastric carcinomas [21], [22]. In contrast, c-Met expression was correlated with advanced stage, in gastric and CRCs in other studies [2], [7]

On the other hand, c-Met in our studied gastric carcinomas was positively associated with non-mucinous adenocarcinomas, intestinal type adenocarcinomas, and lower histologic grades $(p<0.05)$ and that was in concordance with other studies that reported also a statistically significant difference in the c-Met expression across the Lauren histological subtypes [23], [24]. Similarly, in the studied CRCs, c-Met was more detected in non-mucinous than mucinous tumors although did not reach statistical significance but was equally expressed in Grades II and III CRCs.

The discrepancy of reported results from the different studies may be attributed to different sample size and different scoring system for c-Met interpretation.

In the present work, CRCs and colorectal adenomas demonstrating high grade dysplasia expressed c-Met in $50 \%$ and $78.6 \%$ of cases, respectively, while colorectal adenomas with low grade dysplasia were negative for c-Met with statistically significant relationship ( $p<0.001$ ), supporting the oncogenic role of c-Met in cancer progression. Similarly reported by other studies that c-Met was overexpressed in the colorectal cancer tissue [2], [20].

p53 is the most frequent mutated tumor suppressor gene in human malignancies which was expressed in $56.1 \%$ in our studied gastric carcinomas and in $72.2 \%$ of our studied CRCs with only statistical significance reported with intestinal rather than diffuse gastric carcinomas $(p=0.03)$ and without significant correlation with other clinico-pathologic data as tumor site, histologic type, grade, and stage $(p>0.05)$ in both CRCs and gastric carcinomas.

Table 6: The correlation between c-Met and P 53 expression with different clinicopathological parameters in gastric carcinomas

\begin{tabular}{|c|c|c|c|c|c|c|c|c|c|c|}
\hline \multirow[t]{2}{*}{ Clinicopathological data } & \multicolumn{5}{|c|}{ c-Met } & \multicolumn{5}{|c|}{ P 53} \\
\hline & \multicolumn{2}{|c|}{ Negative } & \multicolumn{2}{|c|}{ Positive } & \multirow[t]{2}{*}{$\mathrm{p}$ value } & \multicolumn{2}{|c|}{ negative } & \multicolumn{2}{|c|}{ Positive } & \\
\hline \multicolumn{9}{|l|}{ Histologic Type } & & \\
\hline Adenocarcinoma & 16 & $34.8 \%$ & 30 & $65.2 \%$ & 0.008 & 20 & $43.5 \%$ & 26 & $56.5 \%$ & 0.909 \\
\hline Mucinous and signet & 14 & $70.0 \%$ & 6 & $30.0 \%$ & & 9 & $45.0 \%$ & 11 & $55.0 \%$ & \\
\hline \multicolumn{11}{|c|}{ Intestinal versus diffuse carcinomas } \\
\hline Intestinal & 8 & $20.5 \%$ & 31 & $79.5 \%$ & $<0.001$ & 13 & $33.3 \%$ & 26 & $66.7 \%$ & 0.037 \\
\hline Diffuse & 22 & $81.5 \%$ & 5 & $18.5 \%$ & & 16 & $59.3 \%$ & 11 & $40.7 \%$ & \\
\hline \multicolumn{11}{|l|}{ Grade } \\
\hline I, II & 11 & $26.8 \%$ & 30 & $73.2 \%$ & $<0.001$ & 16 & $39.0 \%$ & 25 & $61.0 \%$ & 0.303 \\
\hline III & 19 & $76.0 \%$ & 6 & $24.0 \%$ & & 13 & $52.0 \%$ & 12 & $48.0 \%$ & \\
\hline \multicolumn{11}{|l|}{ Stage } \\
\hline I, II & 21 & $42.9 \%$ & 28 & $57.1 \%$ & 0.472 & 21 & $42.9 \%$ & 28 & $57.1 \%$ & 0.764 \\
\hline III & 9 & $52.9 \%$ & 8 & $47.1 \%$ & & 8 & $47.1 \%$ & 9 & $52.9 \%$ & \\
\hline \multicolumn{11}{|l|}{ Site } \\
\hline Proximal gastric & 8 & $38.1 \%$ & 13 & $61.9 \%$ & 0.412 & 8 & $38.1 \%$ & 13 & $61.9 \%$ & 0.513 \\
\hline Distal gastric & 22 & $48.9 \%$ & 23 & $51.1 \%$ & & 21 & $46.7 \%$ & 24 & $53.3 \%$ & \\
\hline
\end{tabular}




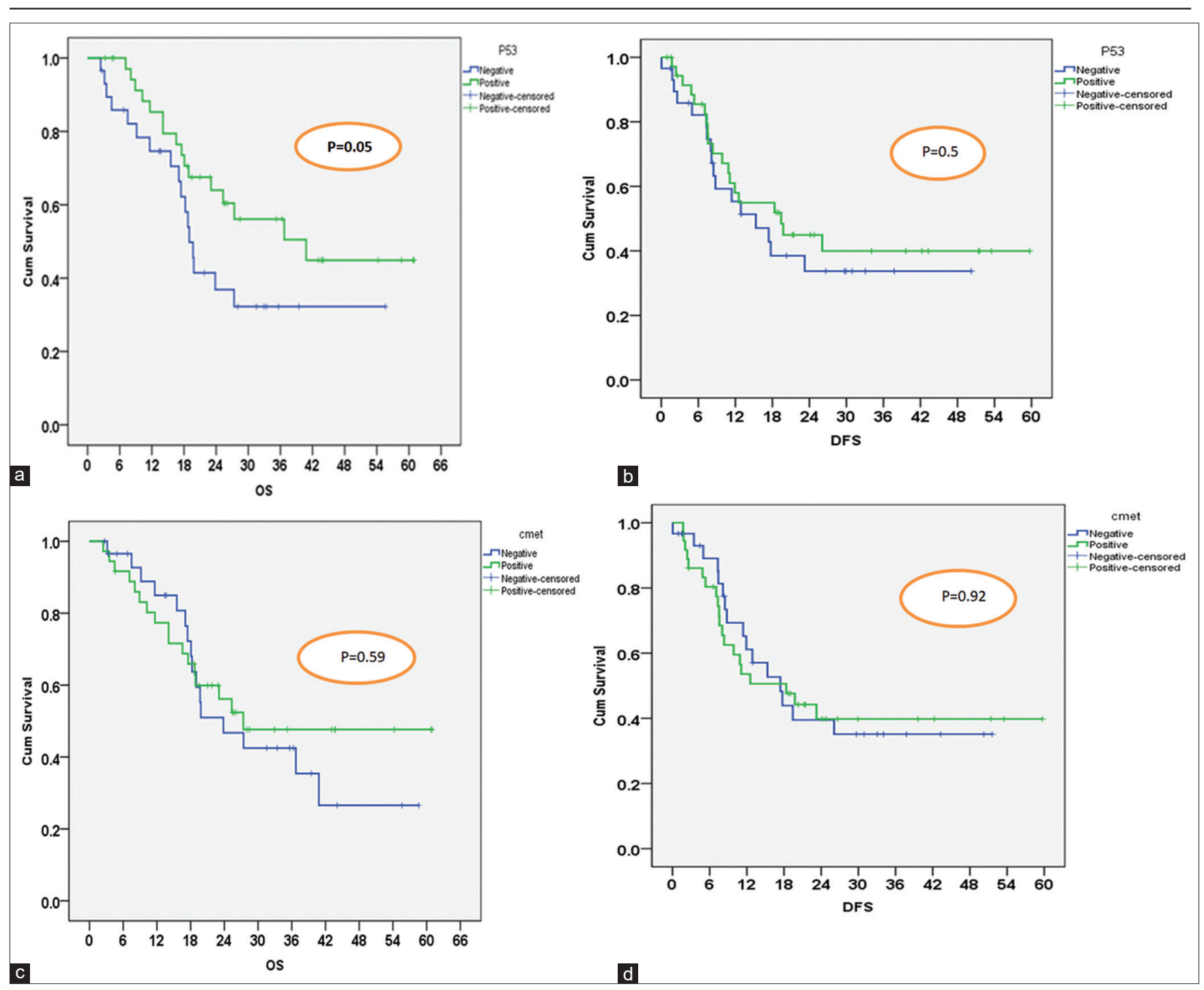

Figure 3: (a): Correlation between overall survival (OS) and p53 expression in gastric carcinomas, (b) correlation between disease-free survival (DFS) and p53 in gastric carcinomas, (c) correlation between OS and c-Met expression in gastric carcinomas, (d) correlation between DFS and C-Met expression in gastric carcinomas

That was with in agreement with Banu et al., as they did not report significant correlation regarding p53 expression with clinicopathologic data in rectal carcinomas [25]. In contrast, P53 accumulation in gastric carcinomas and CRCs was correlated with advanced stage, in study conducted by Mcgregor et al. [26].

Moreover, in the present study, although P 53 was immunohistochemically expressed in the majority of studied CRC cases (72.2\%), all colorectal adenomas studied showed negative $P 53$ expression with statistical difference $p<0.001$ supporting the independent role of p 53 in CRC carcinoma development and that was in agreement with previous study which reported that $46 \%$ of their examined CRC cases were positive for p53 while uniform negative reactivity was seen in colonic adenomas [27]. On the other hand, other studies reported that p53 expression showed a statistically significant difference with degree of adenomatous polyp dysplasia [28], [29].
The use of different antibodies, different detection techniques, and different methods of interpretation for p53 may be attributed to reported contradictory results in different studies.

In the current work, data for survival analysis were available only for gastric carcinoma patients with median DFS reported 17.4 months and, median OS 27.4 months. Higher OS for gastric carcinoma patients (31\%) was reported by American cancer society in 2019 [30]. In contrast, lower OS (22\%) was reported in Japanese study [31].

In our study, the gastric carcinoma patients who showed good response to chemotherapy had significantly better OS, where the median OS in the responders was 19.8 months, while in the nonresponders were 7.5 months, a finding that was also stated in the work done by Achilli et al. [32]. In our study, there was a statistically significant relationship between DFS and the pattern of therapy given, where the 1-year DFS was superior in the adjuvant group (79.3\%). Bang 
Table 7: The correlation of OS and DFS with different clinicopathological parameters and tumor markers (c-Met and $P$ 53) in gastric carcinomas

\begin{tabular}{|c|c|c|c|c|}
\hline \multirow[t]{2}{*}{ Clinicopathological data } & \multicolumn{2}{|c|}{ DFS (months) } & \multicolumn{2}{|c|}{ OS (months) } \\
\hline & Median & P-value & Median & $\mathrm{p}$-value \\
\hline \multicolumn{5}{|l|}{ Sex } \\
\hline Male (52) & 17.7 & \multirow[t]{2}{*}{0.67} & 25.32 & \multirow[t]{2}{*}{0.82} \\
\hline Female (14) & 17.4 & & 36.72 & \\
\hline \multicolumn{5}{|l|}{ Site } \\
\hline Proximal (21) & 17.4 & \multirow[t]{2}{*}{0.66} & 23.8 & \multirow[t]{2}{*}{0.87} \\
\hline Distal (45) & 17.7 & & 36.7 & \\
\hline \multicolumn{5}{|l|}{ Histologic type } \\
\hline Adenocarcinoma (46) & 15.3 & & 27.4 & \multirow[t]{2}{*}{0.84} \\
\hline Mucous and signet ring (20) & 19.4 & 0.54 & 27.4 & \\
\hline \multicolumn{5}{|l|}{ Grade } \\
\hline Well differentiated (33) & 18.3 & \multirow[t]{2}{*}{0.85} & 25.3 & \multirow[t]{2}{*}{0.83} \\
\hline Poor differentiated (33) & 17.4 & & 27.4 & \\
\hline \multicolumn{5}{|l|}{ Intestinal versus diffuse } \\
\hline Intestinal (39) & 18.3 & \multirow[t]{2}{*}{0.74} & 40.8 & \multirow[t]{2}{*}{0.36} \\
\hline Diffuse (27) & 15.3 & & 19.8 & \\
\hline \multicolumn{5}{|l|}{ Tumor depth of invasion } \\
\hline $\mathrm{T} 1,2(16)$ & 15.3 & & 27.4 & \multirow[t]{2}{*}{0.93} \\
\hline T3,4 (50) & 17.4 & 0.8 & 25.3 & \\
\hline \multicolumn{5}{|l|}{ Lymph nodes } \\
\hline Node negative (30) & * & \multirow[t]{2}{*}{0.11} & * & \multirow[t]{2}{*}{0.03} \\
\hline Node positive (36) & 11.9 & & 18.2 & \\
\hline \multicolumn{5}{|l|}{ Tumor, node, and metastasis stage } \\
\hline Stage I, II (49) & 17.7 & \multirow[t]{2}{*}{0.8} & 27.4 & 0.28 \\
\hline Stage III (17) & 9.8 & & 18.1 & \\
\hline P 53 & & & & \\
\hline Negative (29) & 15.3 & & 18.9 & 0.05 \\
\hline Positive (37) & 19.4 & 0.52 & 40.8 & \\
\hline c-Met & & & & \\
\hline Negative (30) & 17.4 & & 23.8 & 0.59 \\
\hline Positive (36) & 18.3 & 0.92 & 27.3 & \\
\hline Pattern of chemotherapy & & & & \\
\hline Pre-operative (9) & 4.9 & & 18.7 & 0.07 \\
\hline Post-operative (37) & 22.3 & & 27.3 & \\
\hline pre and post (11) & 11.4 & 0.006 & 23.8 & \\
\hline Response to chemotherapy & & & & \\
\hline Response (CR, RD) (16) & 7.3 & & 19.8 & 0.04 \\
\hline No response (SD) (4) & 4.9 & 0.48 & 7.5 & \\
\hline Chemotherapy with radiotherap & & & & \\
\hline No (34) & 12.8 & 0.54 & 19.8 & 0.61 \\
\hline Yes (32) & 19.7 & & 27.3 & \\
\hline Type of operation & & & & \\
\hline Subtotal gastrectomy (52) & 17.7 & & 23.04 & 0.59 \\
\hline Total gastrectomy (14) & 17.4 & 0.94 & 36.72 & \\
\hline
\end{tabular}

et al., 2010, similarly reported improved DFS with postoperative chemotherapy [33].

In our work, the median OS for gastric carcinoma patients was superior in the node negative group (not reached), while in the node positive group (18.2 months) $(p=0.03)$, this was confirmed in many published studies.

In our study, the median OS for patients with gastric carcinoma was superior in the P53 positive patients (40.8 months), while inferior in the negative ones (18.9 months), a finding that is opposite to a meta-analysis done in 2015 that showed tissue p53 overexpression in gastric carcinoma patients was associated with lower overall survival [34], this might be attributed to the fact that in our study most of P53 positive cases were negative for lymph node metastasis, of intestinal type and had $\mathrm{RO}$ resection and as expected the value of complete resection and absence of nodal metastasis as prognostic factors outweighed the P53 mutation effect.

c-Met expression in gastric carcinoma patients did not exhibit any significant correlation with OS or DFS in our study. This was in agreement with other studies [35]. Although, c-Met was a predictor of poor survival in a study carried out by Stuebs et al. [22].
The main limitation of this study was the unavailability of survival data for CRC cases.

\section{Conclusion}

To sum up, in this study, we reported positive expression for both c-Met and p53 in the majority of studied colorectal and gastric carcinomas, supporting their role as potential biomarkers in GIT cancer. c-Met in addition can be addressed as potential target for future therapy. Moreover, statistical positive association of both tumor markers in CRCs compared to colorectal adenomas suggests that c-Met and p53 may have a major role in CRC development and progression.

\section{References}

1. SisikA, Kaya M, Bas G, Basak F, Alimoglu O. CEAand CA 19-9 are still valuable markers for the prognosis of colorectal and gastric cancer patients. Asian Pac J Cancer Prev. 2013;14(7):4289-94. https://doi.org/10.7314/apjcp.2013.14.7.4289 PMid:23991991

2. Gayyed M, El-Maqsoud N, El-Heeny A, Mohammed M. c-MET expression in colorectal adenomas and primary carcinomas with its corresponding metastases. J Gastrointest Oncol. 2015;6(6):618-27.PMid: 26697193

3. Bray F, Ferlay J, Soerjomataram I, Siegel RL, Torre LA, Jemal A. Global cancer statistics: GLOBOCAN estimates of incidence and mortality worldwide for 36 cancers in 185 countries. CA Cancer J Clin. 2018;68(6):394-424. https://doi.org/10.3322/ caac. 21492

PMid:30207593

4. Ibrahim A, Khaled H, Mikhail N, Baraka H, Kamel H. Cancer incidence in Egypt: Results of the national populationbased cancer registry program. J Cancer Epidemiol. 2014;2014:437971. https://doi.org/10.1155/2014/437971 PMid:25328522

5. Jia Y, Dai G, Wang J, Gao X, Zhao Z, Duan Z, et al. c-MET inhibition enhances the response of the colorectal cancer cells to irradiation in vitro and in vivo. Oncol Lett. 2016;11(4):2879-85. https://doi.org/10.3892/ol.2016.4303 PMid:27073569

6. Bradley CA, Salto-Tellez M, Laurent-Puig P, Bardelli A, Rolfo C Tabernero J, et al. Review targeting c-MET in gastrointestinal tumours: Rationale, opportunities and challenges. Nat Rev Clin Oncol. 2017;14(9):562-76. https://doi.org/10.1038/ nrclinonc.2017.40

PMid:28374784

7. Huang TJ, Wang JY, Lin SR, Lian ST, Hsie JS. Overexpression of the c-met protooncogene in human gastric carcinoma. Acta Oncol. 2001;40(5):638-43

PMid:11669338

8. Kumar V, Abbas AK. Fausto N, Aster AC. Pathologic Basis of Diseases. $8^{\text {th }}$ ed. Philadelphia, PA: Saunders; 2004. p. 302-3.

9. Levine AJ, Finlay CA, Hinds PW. p53 is a tumor suppressor 
gene. Cell. 2004;S116:S67-9. https://doi.org/10.1016/ s0092-8674(04)00036-4

10. Petitjean A, Achatz MI, Borresen-Dale AL, Hainaut P, Olivier M. TP53 mutations in human cancers: Functional selection and impact on cancer prognosis and outcomes. Oncogene. 2007;26(15):2157-65. https://doi.org/10.1038/sj.onc.1210302 PMid:17401424

11. Eisenhauera EA, Therasse P, Bogaerts J, Schwartz LH, Sargent D, Ford $\mathrm{R}$, et al. New response evaluation criteria in solid tumours: Revised RECIST guideline; (version 1.1). Eur J Cancer. 2009;45(2):228-47. https://doi.org/10.1016/j. ejca.2008.10.026

PMid:19097774

12. Hamilton SR, Bosman FT, Boffetta P, llyas M, Morreau H, Nakamura S. Carcinoma of the colon and rectum. In: Bosman FT, Carneiro F, Hruban RH, Theise ND, editors. WHO Classification of Tumours of the Digestive System. $4^{\text {th }}$ ed. Lyon: IARC Press; 2010. p. 134-46.

13. Edge SB, Byrd DR, Compton CC, Fritz AG, Greene F, Trotti A. AJCC Cancer Staging Handbook. $7^{\text {th }}$ ed. New York: Springer; 2010. p. 473-206.

14. Fleming M, Ravula S, Tatishchev S, Wang H. Colorectal carcinoma: Pathologic aspects. J Gastrointest Oncol. 2012;3(3):153.] PMid:22943008

15. Rawla P, Sunkara T, Barsouk A. Epidemiology of colorectal cancer: Incidence, mortality, survival, and risk factors. Prz Gastroenterol. 2019;14(2):89-103. https://doi.org/10.5114/ pg.2018.81072

PMid:31616522

16. Chen CY, Wu CW, Lo SS, Hsieh MC, Lui WY, Shen KH. Peritoneal carcinomatosis and lymph node metastasis are prognostic indicators in patients with Borrmann type IV gastric carcinoma. J Hepatogastroenterol. 2002;49(45):387.

PMid:12064011

17. Heitman SJ, Ronksley PE, Hilsden RJ, Manns BJ, Rostom A, Hemmelgarn BR, et al. Prevalence of adenomas and colorectal cancer in average risk individuals: A systematic review and meta-analysis. Clin Gastroenterol Hepatol. 2009;7(12):1272-8. https://doi.org/10.1016/j.cgh.2009.05.032

PMid:19523536

18. Druliner BR, Wang $\mathrm{P}$, Bae $\mathrm{T}$, Baheti $\mathrm{S}$, Slettedahl $\mathrm{S}$, Mahoney $\mathrm{D}$, et al. Molecular characterization of colorectal adenomas with and without malignancy reveals distinguishing genome, transcriptome and methylome alterations. Sci Rep. 2018;8(1):3161. https://doi.org/10.1038/s41598-018-21525-4 PMid:29453410

19. Saigusa S, Toiyama $\mathrm{Y}$, Tanaka $\mathrm{K}$, Yokoe T, Fujikawa $\mathrm{H}$, Matsushita $\mathrm{K}$, et al. Inhibition of HGF/cMET expression prevents distant recurrence of rectal cancer after preoperative chemoradiotherapy. Int J Oncol. 2012;40(2):583-91.] https://doi. org/10.3892/ijo.2011.1200

PMid:21922134

20. Abou-Bakr A, Elbasmi A. C-MET overexpression as a prognostic biomarker in colorectal adenocarcinoma. Gulf J Oncolog. 2013;1(14):28-34. PMid:23996864

21. Guo T, Yang J, Yao J, Zhang Y, Da M, Duan Y. Expression of MACC1 and c-Met in human gastric cancer and its clinical significance. Cancer Cell Int. 2013;13(1):121. https://doi. org/10.1186/1475-2867-13-121 PMid:24325214

22. Stuebs P, Dittmar F, Zierau K, Fahlke J, Ridwelski K, Kristin A, et al. The characteristics of C-MET and HER2 expression in gastric carcinoma and its correlation with clinical-pathological parameters. J Clin Oncol. 2017;35(15):e15566. https://doi. org/10.1200/jco.2017.35.15_suppl.e15566

23. Lee HE, Kim MA, Lee HS, Jung EJ, Yang HK, Lee BL, et al. c-MET in gastric carcinomas: Comparison between protein expression and gene copy number and impact on clinical outcome. $\mathrm{Br} \mathrm{J}$ Cancer. 2012;107:325-33. https://doi.org/10.1038/bjc.2012.237 PMid:22644302

24. Sotoudeh K, Hashemi F, Madjd Z, Sadeghipour A Molanaei S, Kalantary E. The clinicopathologic association of c-MET overexpression in Iranian gastric carcinomas; an immunohistochemical study of tissue microarrays. Diagn Pathol. 2012;7:57. https://doi.org/10.1186/1746-1596-7-57 PMid:22640970

25. Banu L, Sülen S, Selman S, Ellidokuz H, Füzün M, Küpelioğlu A. The clinical significance of P53, P21, and P27 expressions in rectal carcinomas. Appl Immunohistochem Mol Morphol. 2005;13(1):38-44.

PMid: 15722792

26. Mcgregor MJ, Fadhil W, Wharton R, Yanagisawa $\mathrm{Y}$, Presz $M$ Pritchard A, et al. Aberrant P53 expression lacks prognostic or predictive significance in colorectal cancer: Results from the VICTOR trial. Anticancer Res. 2015;35(3):1641-5. PMid:25750322

27. Starzynska T, Bromley M, Ghosh A, Stern PL. Prognostic significance of p53 overexpression in gastric and colorectal carcinoma. $\mathrm{Br} \mathrm{J}$ Cancer. 1992;66(3):558-62. https://doi. org/10.1038/bjc.1992.314

PMid:1520594

28. Vernillo R, Lorenzi B, Banduccci T, Minacci C, Vindigni C, Fei AL, et al. Immunohistochemical expression of p53 and ki67 in colorectal adenomas and prediction of malignancy and development of new polyps. Int J Biol Markers. 2008;23(2):8995. https://doi.org/10.1177/172460080802300205 PMid:18629781

29. Sousa WA, Rodrigues LV, Silva RG Jr., Vieira FL. Immunohistochemical evaluation of p53 and Ki-67 proteins in colorectal adenomas. Arq. Gastroenterol. 2012;49(1):35-40. https://doi.org/10.1590/s0004-28032012000100007 PMid:22481684

30. American Cancer Society. Cancer Facts and Figures. Atlanta, GA American Cancer Society; 2019. Available from: http:// www.cancer.org/content/dam/cancer-org/research/cancerfacts-and-statistics/annual-cancer-facts-and-figures/2019/ cancer-facts-and-figures-2019.

31. Shiraishi N, Sato K, Yasuda K, Inomata M, Kitano A. Multivariate prognostic study on large gastric cancer. J Surg Oncol. 2007;96(1):14-8. https://doi.org/10.1002/jso.20631 PMid:17582596

32. Achilli P, Martini PD, Ceresoli M, Mari GM, Costanzi A, Maggioni $\mathrm{D}$, et al. Tumor response evaluation after neoadjuvant chemotherapy in locally advanced gastric adenocarcinoma: A prospective, multi-center cohort study. J Gastrointest Oncol. 2017;8(6):1018-25. https://doi.org/10.21037/jgo.2017.08.13 PMid:29299362

33. Bang YJ, Van Cutsem E, Feyereislova A, Chung HC, Shen L, Sawaki A, et al. Trastuzumab in combination with chemotherapy versus chemotherapy alone for treatment of HER2-positive advanced gastric or gastro-oesophageal junction cancer (ToGA): A phase 3, open-label, randomised controlled trial. Lancet. 2010;376(9742):687-97. https://doi.org/10.1016/ s0140-6736(10)61121-x PMid:20728210

34. Yildirim M, Kaya V, Demirpence O, Gunduz S, Bozcuk H. 
Prognostic significance of p53 in gastric cancer: A metaanalysis. Asian Pac J Cancer Prev. 2015;16(1):327-32. https:// doi.org/10.7314/apjcp.2015.16.1.327

PMid:25640374

35. Retterspitz MF, Mönig SP, Schreckenberg S, Schneider PM,
Hölscher AH, Dienes HP, et al. Expression of \{beta\}catenin, MUC1 and c-met in diffuse-type gastric carcinomas: Correlations with tumour progression and prognosis. Anticancer Res. 2010;30(11):4635-41.

PMid:21115917 